\title{
Comparison between first and second wave among critically ill COVID-19 patients admitted to a French ICU: no prognostic improvement during the second wave?
}

\author{
Damien Contou* ${ }^{*}$, Megan Fraissé, Olivier Pajot, Jo-Anna Tirolien, Hervé Mentec and Gaëtan Plantefève
}

Keywords: SARS-CoV-2, COVID-19, France, Corticoids, ICU, Mortality, ARDS

As many countries in Europe, France faced a second wave COVID-19 pandemic since September, 2020. During the first wave, intensivists faced an unprecedented massive admission of patients with COVID-19 pneumonia requiring invasive mechanical ventilation, sometimes leading to ICUs saturation. They discovered the stereotypical course of this previously unknown disease with its own specificities including the need for deep sedation and neuromuscular blockade, the increased risk of thrombotic and hemorrhagic events $[1,2]$, and the prolonged duration of mechanical ventilation [3] with high rate of delirium [4]. Importantly, several randomized controlled trials conducted during this first wave highlighted the beneficial effects of early administration of glucocorticoids for critically ill COVID-19 patients $[5,6]$.

One can legitimately assume that the experience gained during the first wave may have contributed to a better management and outcome among critically ill COVID-19 patients admitted during the second wave.

We therefore compared the characteristics and the outcome between patients admitted to our 41-bed COVID19 ICU for acute respiratory failure due to COVID-19 (RT-PCR positive for SARS-CoV-2) during the first wave (from March 13th to May 27th, 2020) and those admitted

*Correspondence: damien.contou@ch-argenteuil.fr Service de Réanimation Polyvalente, Centre Hospitalier Victor Dupouy, 69, rue du Lieutenant-Colonel Prud'hon, 95100 Argenteuil, France to our 18-bed ICU during the second wave (from August 19th to December 7th, 2020).

COVID-19 patients without acute respiratory failure, those transferred to other ICUs or still hospitalized in ICU were not included.

Eighty-two patients were admitted during the first wave and 50 during the second wave. Comparison between first and second wave regarding patients' characteristics, ICU scores, comorbidities, biological data, administered treatments and outcome is detailed in the Table 1. Patients did not differ between the two waves with similar age, ICU scores and comorbidities. Contrary to the first wave, all the patients admitted during the second wave received early glucocorticoids and intermediate or full-dose thromboprophylaxis at ICU admission.

Compared to the first wave, we observed a lower proportion of patients requiring invasive mechanical ventilation and a lower rate of thrombotic events. The delay between ICU admission and tracheal intubation was longer during the second wave. ICU mortality $(50 \%$ vs. $52 \%, p=0.96)$ and duration of ICU stay did not differ between the two waves.

The Kaplan-Meier survival analysis did not show significant difference between the two waves $(p=0.90$, logrank test) (Fig. 1).

We herein report the first study comparing the outcome of critically ill COVID-19 patients between first and second wave in France. Despite a better understanding of COVID-19 with significant treatment original author(s) and the source, provide a link to the Creative Commons licence, and indicate if changes were made. The images or other third party material in this article are included in the article's Creative Commons licence, unless indicated otherwise in a credit line to the material. If material is not included in the article's Creative Commons licence and your intended use is not permitted by statutory regulation or exceeds the permitted use, you will need to obtain permission directly from the copyright holder. To view a copy of this licence, visit http://creativecommons.org/licenses/by/4.0/. The Creative Commons Public Domain Dedication waiver (http://creativeco mmons.org/publicdomain/zero/1.0/) applies to the data made available in this article, unless otherwise stated in a credit line to the data. 
Table 1 Comparison between critically ill patients with SARS-CoV-2 pneumonia admitted during the first $(n=82)$ and the second $(n=50)$ COVID-19 wave

$\begin{array}{lll}\begin{array}{l}\text { First wave } \\ n=82\end{array} & \begin{array}{l}\text { Second wave } \\ n=50\end{array} & p \text { value }\end{array}$

\section{Patient's characteristics and ICU scores}

Male sex

Age, years

SAPS II

SOFA

Main comorbidities

Obesity (body mass index $\geq 30 \mathrm{~kg} / \mathrm{m}^{2}$ )

Arterial hypertension

Diabetes mellitus

Ischemic cardiopathy

Cerebro-vascular disease

Chronic kidney failure

Chronic respiratory disease

Immunocompromised status

\section{Main delays}

Days between disease onset and ICU admission

$>7$ days between disease onset and ICU admission

Days between hospital admission and ICU admission

\section{Biological data at ICU admission}

D-dimers ( $\mathrm{ng} / \mathrm{mL}$ )

Prothrombin time (\%)

Fibrinogen ( $\mathrm{g} / \mathrm{L})$

Platelets count $(\mathrm{G} / \mathrm{L})$

\section{Treatment administered at ICU admission}

Glucocorticoids ${ }^{\mathrm{a}}$

Intermediate or full-dose thromboprophylaxis

Antibiotic therapy for bacterial co-infection at ICU admission

Antiviral drugs (lopinavir-ritonavir or remdesivir)

Tocilizumab

\section{Outcome in the ICU}

Invasive mechanical ventilation (IMV)

Days between ICU admission and IMV

Days between disease onset and IMV

Ventilator associated pneumonia

Prone positioning

Duration of IMV

Renal replacement therapy

Vasopressor support

Thrombotic events during ICU stay

Hemorrhagic events during ICU stay

Length of ICU stay, days

Overall ICU mortality

ICU mortality among patients requiring IMV

$\begin{array}{lll}66(81) & 38(76) & 0.70 \\ 62[55-70] & 65[61-69] & 0.20 \\ 33[24-41] & 29[22-37] & 0.23 \\ 4[3-7] & 4[3-4] & 0.07 \\ & & \\ 37(46) & 22(44) & 0.94 \\ 52(63) & 30(60) & 0.84 \\ 35(43) & 22(44) & 1.00 \\ 8(10) & 5(10) & 1.00 \\ 7(9) & 3(6) & 0.74 \\ 7(9) & 5(10) & 0.77 \\ 18(23) & 14(28) & 0.62 \\ 11(13) & 8(16) & 0.88\end{array}$

$8[7-12]$

$10[8-12]$

0.42

$50(64)$

37 (74)

0.33

2 [1-4]

3 [1-4]

0.30

2510 [1655-9222]

1665 [1060-3372]

0.04

85 [74-96]

90 [83-101]

0.08

7.6 [6.0-8.7]

7.4 [6.2-8.4]

0.75

225 [170-287]

267 [199-344]

0.03

10 (12)

$50(100)$

$<0.001$

46 (57)

$50(100)$

$<0.001$

18 (22)

14 (29)

0.52

$0(0)$

$0(0)$

1.00

$0(0)$

$0(0)$

1.00

$72(88)$

32 (64)

0.01

2 [1-3]

11 [8-13]

4 [2-5]

$<0.001$

53/72 (74)

14 [11-17]

0.01

$52 / 72(72)$

24/32 (75)

0.97

19 [10-30]

$30 / 32$ (94)

0.03

24 (29)

17 [8-31]

0.60

52 (63)

12 (27)

0.98

34 (42)

25 (53)

0.34

15 (18)

8 (17)

0.01

16 [8-30]

9 (18)

1.00

41 (50)

14 [9-30]

0.88

41/72 (57)

Continuous variables are reported as median [Interquartile range] and compared between groups using the Student $t$ test. Categorical variables are reported as numbers (percentages) and compared using $X^{2}$ test. A $p$ value $<0.05$ was considered significant

ICU, Intensive Care Unit; IMV, Invasive Mechanical Ventilation; SAPS2, Simplified Acute Physiology Score; SOFA, Sepsis-related Organ Failure Assessment

a According to CAPE COVID [5] (first wave) or RECOVERY [6] (second wave) protocols 


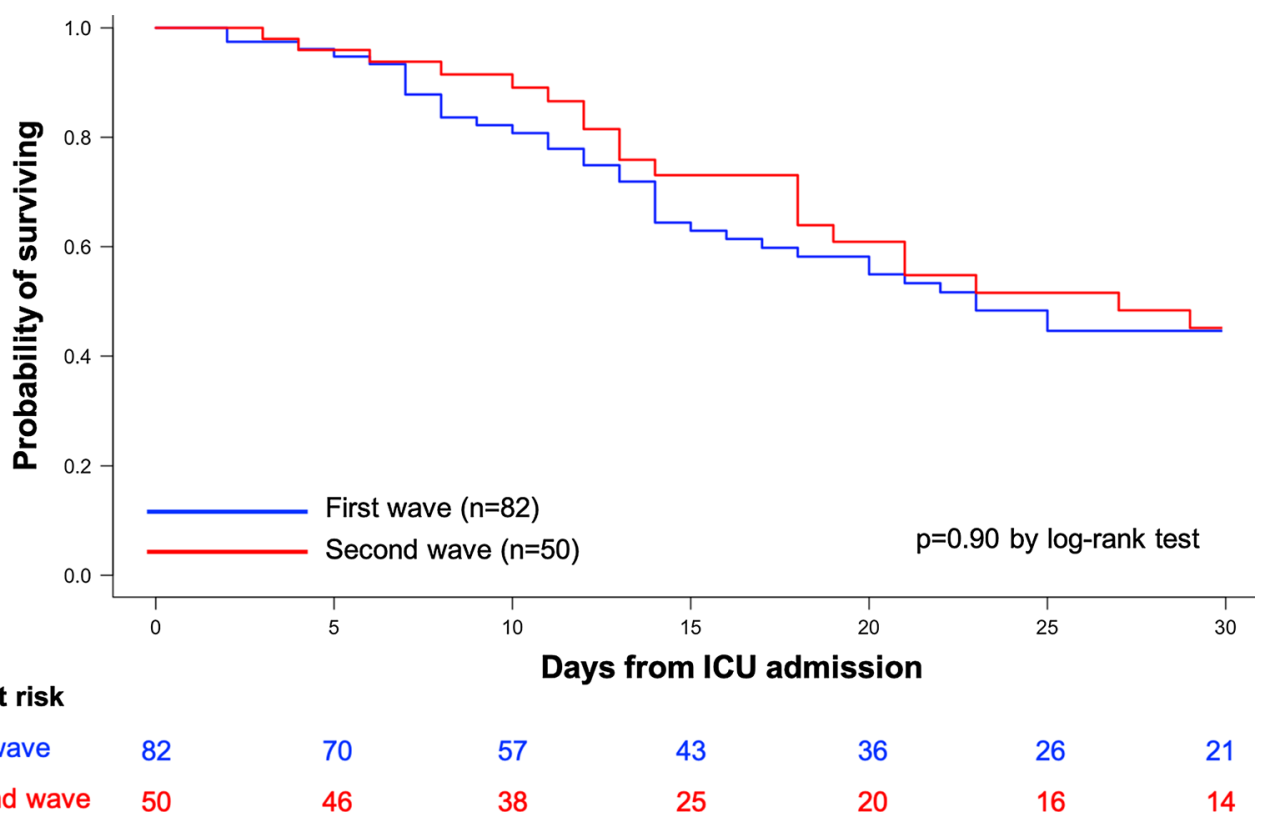

Fig. 1 Kaplan-Meier survival estimates during the 30 days following ICU admission of COVID-19 patients admitted during the first wave (blue curve) and the second wave (red curve)

modification including systematic and early administration of glucocorticoids as well as intermediate/ full dose thromboprophylaxis, we did not observe any decrease in ICU mortality, with still half of the patients dying in our ICU.

However, patients admitted during the second wave were less likely to require invasive mechanical ventilation with a longer delay between ICU admission and tracheal intubation, potentially related to early administration of glucocorticoids [6]. However, this longer delay questions about the higher, albeit not statistically significant, ICU mortality observed in our intubated patients during the second wave.

The lower rate of thrombotic events observed during the second wave is likely inherent to the increased intensity of thromboprophylaxis even if a lower rate of $\mathrm{CT}$ pulmonary angiographies during the second wave cannot be ruled out.

The strengths of our study include the similar typology and severity of the patients during both waves making relevant the comparison. Its monocenter design, implying similar criteria of ICU admission and similar criteria of tracheal intubation by the same team of intensivists during both periods, may also be considered as a strength.

\section{Acknowledgements}

We warmly acknowledge Dr Elsa Logre, Dr Radj Cally, Dr Olivia Picq, Dr Florence Sarfati, Dr Paul Desaint and all the residents who took care of the patients.

\section{Author's contributions}

$D C$ is responsible for the conception and design. All the authors took care of the patients. DC and MF are responsible for data acquisition. All the authors were responsible for analysis and interpretation of data. All authors read, critically reviewed and approved the final manuscript. DC takes responsibility for the paper as a whole.

\section{Funding}

No funding.

\section{Availability of data and materials}

The dataset used and analyzed for the current study is available from the corresponding author on reasonable request.

\section{Ethics approval and consent to participate}

This study was conducted in accordance with the amended Declaration of Helsinki and was approved by the Institutional Review Board (CE 2020-85) of the French Intensive Care Society on the 27th of November 2020.

\section{Consent for publication}

Not applicable.

\section{Competing interests}

The authors declare that they have no competing interests.

Received: 15 December 2020 Accepted: 18 December 2020

Published online: 04 January 2021

\section{References}

1. Helms J, Tacquard C, Severac F, Leonard-Lorant I, Ohana M, Delabranche $X$, et al. High risk of thrombosis in patients with severe SARS-CoV-2 infection: a multicenter prospective cohort study. Intensive Care Med. 2020;46:1089-98.

2. Fraissé $\mathrm{M}$, Logre $\mathrm{E}$, Pajot $\mathrm{O}$, Mentec $\mathrm{H}$, Plantefève $\mathrm{G}$, Contou D. Thrombotic and hemorrhagic events in critically ill COVID-19 patients: a French monocenter retrospective study. Crit Care. 2020;24:275. 
3. Wang Y, Zhang D, Du G, Du R, Zhao J, Jin Y, et al. Remdesivir in adults with severe COVID-19: a randomised, double-blind, placebo-controlled, multicentre trial. Lancet. 2020;395:1569-78.

4. Helms J, Kremer S, Merdji H, Schenck M, Severac F, Clere-Jehl R, et al. Delirium and encephalopathy in severe COVID-19: a cohort analysis of ICU patients. Crit Care. 2020;24:491.

5. Dequin P-F, Heming N, Meziani F, Plantefève G, Voiriot G, Badié J, et al. Effect of hydrocortisone on 21-day mortality or respiratory support among critically ill patients with COVID-19: a randomized clinical trial. JAMA. 2020;324:1298-306.
6. Horby P, Lim WS, Emberson JR, Mafham M, Bell JL, RECOVERY Collaborative Group, et al. Dexamethasone in hospitalized patients with Covid19-preliminary report. N Engl J Med. 2020. https://doi.org/10.1056/NEJMo a2021436.

\section{Publisher's Note}

Springer Nature remains neutral with regard to jurisdictional claims in published maps and institutional affiliations.
Ready to submit your research? Choose BMC and benefit from:

- fast, convenient online submission

- thorough peer review by experienced researchers in your field

- rapid publication on acceptance

- support for research data, including large and complex data types

- gold Open Access which fosters wider collaboration and increased citations

- maximum visibility for your research: over $100 \mathrm{M}$ website views per year

At BMC, research is always in progress.

Learn more biomedcentral.com/submissions 